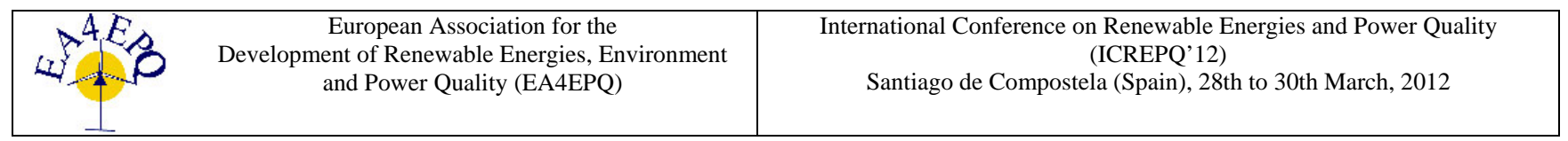

\title{
Influence of the photovoltaic generation in a small distribution network
}

\author{
E. Tarancón Andrés ${ }^{1}$, L.A. Fernández Jiménez ${ }^{2}$, E. García Garrido² ${ }^{2}$ A. Falces de Andrés ${ }^{2}$, P. Lara Santillán², \\ P. Zorzano Santamaría ${ }^{2}$ \\ ${ }^{1}$ Department of Mechanical Engineering \\ ${ }^{2}$ Department of Electrical Engineering \\ E.T.S.I.I., La Rioja University \\ C/Luis de Ulloa 20. 26004, Logroño (Spain)
}

Phone/Fax number:+0034 941299531, e-mail: efren.tarancon@unirioja.es, luisalfredo.fernandez@unirioja.es

\begin{abstract}
In this paper are presented the results of a study carried out with the data of a electrical energy distribution network in a village in the region of La Rioja (Spain). In this distribution network, property of a small utility, is connected a photovoltaic power plant with a capacity comparable with the total load connected to the network in some hours. In the study there have been used actual load and generation data, discussing the influence of the photovoltaic generation on the net demand of the village over a period of two years (2009-2010). This study is a first phase for the application of demand side management actions for adjusting the load curves with generation curves. In a second phase the influence of new distributed generation facilities, based on renewable sources (wind, biomass, cogeneration, etc.) will be considered in order to minimize the dependence of the village from external supplies.
\end{abstract}

\section{Key words}

Distribution networks, load curves, photovoltaic generation, demand side management.

\section{Introduction}

This paper presents the results obtained with the analysis of electric power consumptions in the village of Autol. This village, with a population near 5000 inhabitants, is placed in the region of La Rioja, in the north of Spain. The village is fed by an electric distribution network, managed by a small utility (Electra Autol S.A.). A photovoltaic (PV) plant, with a capacity of $2 \mathrm{MW}$, is connected to the distribution network.

For the study described in the paper, data with load consumption and PV generation values were available on an hourly basis, and they correspond to the years 2009 and 2010.
The study aims to analyze the influence that the photovoltaic generation has had on the global load of the whole distribution network. The results will provide a base scenario for implementing a demand side management (DSM) technique, previously used in other studies $[6,7,8]$, and with the addition of other generation plants [1,2,3], trying to make self-sufficient all the system covered by that distribution network [4].

The paper is structured as follows: In the second section is described the small power system (the distribution network) under study, as well as the load and generation data, showing the network size and its characteristics. In the third and forth sections are analyzed the data with annual, biennial, and seasonal studies, and the days with special characteristics are also analyzed. The last section presents the conclusions.

\section{Distribution network under study}

The electrical system under study is a small distribution network that feed loads in the village of Autol (La Rioja). This distribution network belongs and is managed by a small utility, Electra Autol SA. The network is composed by a 15 MVA, 66/13.2 kV power substation (two 7.5 MVA power transformers). This small distribution network is only connected to the power system through the aforementioned power substation.

Several $13.2 \mathrm{kV}$ power lines connect the substation to the low voltage (LV) substations and to the switching substations. High voltage (HV) consumers $(13.2 \mathrm{kV})$ are connected to the network through their own power substations, and low voltage customers are connected through the utility's low voltage power substations. 
Table I presents the main technical data of the distribution network under study.

Table I. - Distribution network data.

\begin{tabular}{|l|c|}
\hline HV overhead power line $(\mathrm{km})$ & 25.458 \\
\hline HV underground power line $(\mathrm{km})$ & 16.725 \\
\hline LV overhead power line $(\mathrm{km})$ & 33.755 \\
\hline LV underground power line $(\mathrm{km})$ & 19.314 \\
\hline Number of LV power substation & 37 \\
\hline Installed capacity in LV power substation (KVA) & 17515 \\
\hline Number of private customers LV power substations & 38 \\
\hline Number of clients & 3174 \\
\hline Number of generation plants & 1 \\
\hline Installed capacity in power plants (kVA) & 2000 \\
\hline
\end{tabular}

With this distribution network, Electra Autol SA is able to meet the load of the village of Autol, with an area of 86.3 $\mathrm{km}^{2}$ and a population of 4624 inhabitants. The village is placed in the region of La Rioja, in the north of Spain, and the altitude is $458 \mathrm{~m}$.

\section{Preliminary results}

For this study all the data corresponding to the years 2009 and 2010 were available. The data include hourly records with the consumption of the whole network registered in the HV power substation, as well as hourly generation data of the PV plant. The data were analyzed month by month, calculating the penetration level, which is defined as the percentage, with respect to the total consumption (the load registered in $\mathrm{HV}$ power substation plus the power generation), represented by the power generation in the PV plant. The results are shown in Table II.

The electric energy consumed and generated in 2009 were 30902.85 MWh and 4022.94 MWh, respectively. The percentage of the generated energy with respect to the global load was, in 2009, 13.02\%. For the year 2010 the electric energy consumed and generated values were 30776.14 MWh and 3798.99 MWh, respectively, with a percentage of $12 \%$.

Figure 1 shows the monthly average penetration level (percentage of the PV generation with respect to the global load) for all the months corresponding to the period of study.

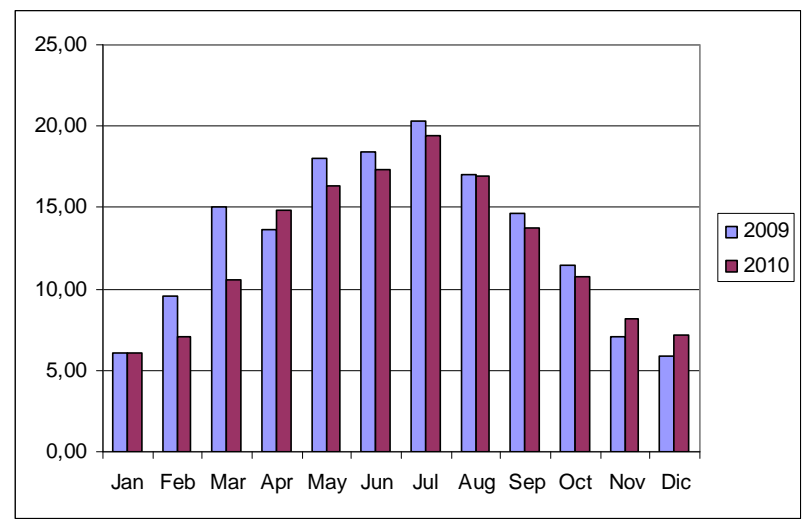

Fig. 1. Penetration level in percentage.
Table II. - Monthly results for the years 2009 and 2010.

\begin{tabular}{|l|c|c|c|}
\hline & $\begin{array}{c}\text { Load } \\
(\mathrm{kWh})\end{array}$ & $\begin{array}{c}\text { Generation } \\
(\mathrm{kWh})\end{array}$ & $\begin{array}{c}\text { Penetration } \\
(\%)\end{array}$ \\
\hline Jan 2009 & $\mathbf{2 7 8 3 6 8 1}$ & 168006 & 6.04 \\
\hline Feb 2009 & 2430859 & 231687 & 9.53 \\
\hline Mar 2009 & 2551712 & 384828 & 15.08 \\
\hline Apr 2009 & 2396629 & 327607 & 13.67 \\
\hline May 2009 & 2481407 & 447126 & 18.02 \\
\hline Jun 2009 & 2467570 & 453812 & 18.39 \\
\hline Jul 2009 & 2632803 & $\mathbf{5 3 4 1 1 5}$ & $\mathbf{2 0 . 2 9}$ \\
\hline Aug 2009 & 2677444 & 457124 & 17.07 \\
\hline Sep 2009 & 2529064 & 369595 & 14.61 \\
\hline Oct 2009 & 2710500 & 309701 & 11.43 \\
\hline Nov 2009 & 2550904 & 181582 & 7.12 \\
\hline Dec 2009 & 2690277 & 157757 & 5.86 \\
\hline Jan 2010 & 2398689 & 146510 & 6.11 \\
\hline Feb 2010 & 2444364 & 173222 & 7.09 \\
\hline Mar 2010 & 2664667 & 281571 & 10.57 \\
\hline Apr 2010 & 2499710 & 372112 & 14.89 \\
\hline May 2010 & 2465927 & 402950 & 16.34 \\
\hline Jun 2010 & 2361828 & 409836 & 17.35 \\
\hline Jul 2010 & 2623364 & 508872 & 19.40 \\
\hline Aug 2010 & 2610872 & 441561 & 16.91 \\
\hline Sep 2010 & 2580776 & 355619 & 13.78 \\
\hline Oct 2010 & 2759148 & 296357 & 10.74 \\
\hline Nov 2010 & 2593200 & 210943 & 8.13 \\
\hline Dec 2010 & 2773594 & 199446 & 7.19 \\
\hline
\end{tabular}

Taking into account the data shown in Table II and Fig. 1 , the behaviour of the generation with respect to the global load was similar both years. In the month with greater PV generation, July, the penetration level of PV energy was around $20 \%$ of the global load. In the months with lower PV generation, the penetration of this energy to the global demand was around $10 \%$.

\section{Data and analysis of consumption and demand}

In Fig. 2 and Fig. 3 are shown the maximum hourly average load and maximum hourly average PV generation values for each one of the months in the studied period. As it is shown in Fig. 2, the maximum hourly average load ranges from 5000 to $6300 \mathrm{kWh}$, while the maximum hourly average PV generation ranges from 1760 to $1830 \mathrm{kWh}$.

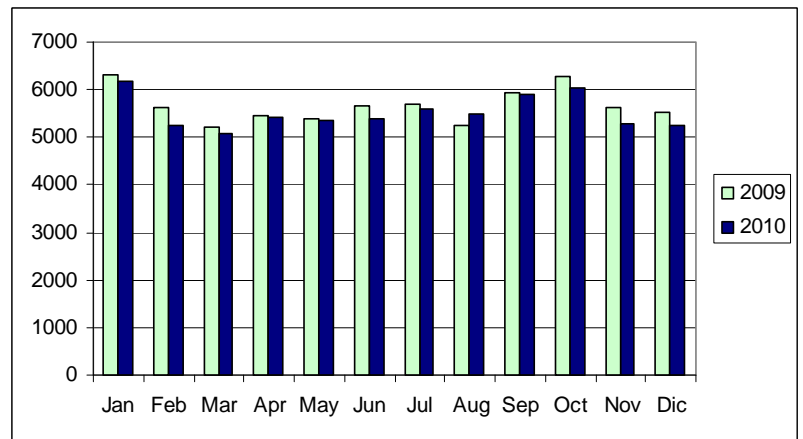

Fig. 2. Maximum hourly average load for each month. 


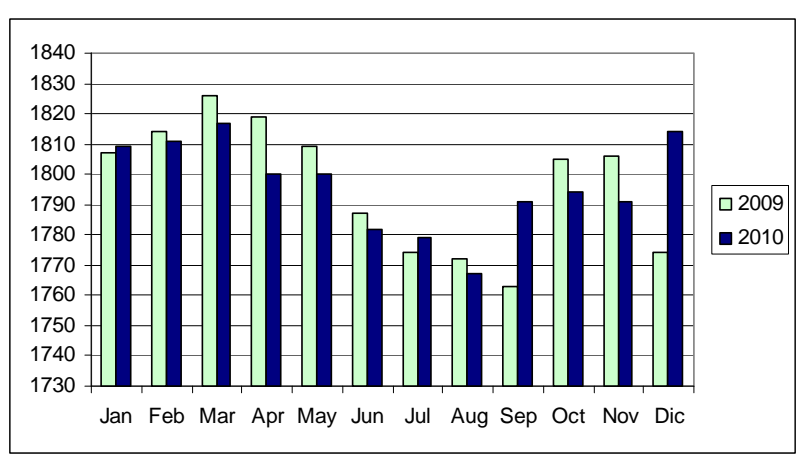

Fig. 3. Maximum hourly average PV generation for each month.

Curiously, the hour with the maximum PV generation value corresponds to spring season, instead summer season, as it could be expected. That hour was the period from 13:00 to 14:00 on March 25, 2009, with a value of $1826 \mathrm{kWh}$, what represents the $43.1 \%$ of the global load, for the whole distribution network, at the same hour. The average temperature was of $15^{\circ} \mathrm{C}$ for that hour.

In Table III are shown the most relevant results derived from the analysis carried out for each one of the years under study. In that table, h represents the hour of the day, $\mathrm{T}$ represents the average temperature at that hour, $\mathrm{L}$ represents the load, and G the PV generation. The first row includes the data referred to the hour with the maximum PV generation (March 25, 2009); the second row includes the data corresponding to the day with the maximum load; the third row includes the data corresponding to the day with the minimum load; and the fourth row includes the data corresponding to the day with the maximum penetration level.

Table III. - Most relevant hourly values.

\begin{tabular}{|c|c|c|c|c|c|}
\hline \multicolumn{7}{|c|}{$\mathbf{2 0 0 9}$} \\
\hline Date & $\mathrm{h}$ & $\begin{array}{c}\mathrm{T} \\
\left({ }^{\circ} \mathrm{C}\right)\end{array}$ & $\begin{array}{c}\mathrm{L} \\
(\mathrm{kWh})\end{array}$ & $\begin{array}{c}\mathrm{G} \\
(\mathrm{kWh})\end{array}$ & $\begin{array}{c}\mathrm{G} / \mathrm{L} \\
(\%)\end{array}$ \\
\hline Mar 25 & $13-14$ & 15 & 4238 & $\mathbf{1 8 2 6}$ & 43.1 \\
\hline Jan 7 & $11-12$ & 2 & $\mathbf{6 3 0 2}$ & 1465 & 23.25 \\
\hline Jun 21 & $19-20$ & 21 & $\mathbf{1 5 8 6}$ & 180 & 11.35 \\
\hline May 3 & $8-9$ & 13 & 2582 & 1762 & $\mathbf{6 8 . 2 4}$ \\
\hline \multicolumn{7}{|c|}{$\mathbf{2 0 1 0}$} \\
\hline Date & $\mathrm{h}$ & $\begin{array}{c}\mathrm{T} \\
\left({ }^{\circ} \mathrm{C}\right)\end{array}$ & $\begin{array}{c}\mathrm{L} \\
(\mathrm{kWh})\end{array}$ & $\begin{array}{c}\mathrm{G} \\
(\mathrm{kWh})\end{array}$ & $\begin{array}{c}\mathrm{G} / \mathrm{L} \\
(\%)\end{array}$ \\
\hline Mar 15 & $13-14$ & 13.6 & 4499 & $\mathbf{1 8 1 7}$ & 40.39 \\
\hline Jan 27 & $12-13$ & 3 & $\mathbf{6 1 9 0}$ & 1793 & 28.97 \\
\hline Jan 23 & $10-11$ & 6.4 & $\mathbf{1 2 2 2}$ & 82 & 6.71 \\
\hline Feb 28 & $9-10$ & 10 & 2402 & 1644 & $\mathbf{6 8 . 4 4}$ \\
\hline
\end{tabular}

The hours with the highest load were from 11:00 to 12:00 on January 7, 2009, and from 12:00 to 13:00 on January 27, 2010. The loads, for both hours, were 6302 and 6190 kWh, respectively. The penetration level values of PV energy in the system were $23.25 \%$ and $28.97 \%$. The temperature at those hours was $2{ }^{\circ} \mathrm{C}$ and $3{ }^{\circ} \mathrm{C}$, respectively.

The highest penetration levels were reached at 8:00 on May 3, 2009, and at 9:00 on February 28, 2010, with $68.24 \%$ and $68.44 \%$, respectively.
Notice that the PV generation achieves its best results in hours with average temperature between 10 and $15{ }^{\circ} \mathrm{C}$, although with temperature values as low as 2 or $3{ }^{\circ} \mathrm{C}$, the PV generation achieves significant values $(1465 \mathrm{kWh}$, or $1793 \mathrm{kWh}$, what corresponds to penetration values of $23.25 \%$ and $28.97 \%$, respectively).

Tables IV and V show the results obtained with a daily analysis. In such tables are presented the maximum and minimum daily average loads for each month. The maximum and minimum penetration levels are also presented.

Table IV. - Results of the daily analysis for 2009.

\begin{tabular}{|l|r|c|c|r|r|r|}
\hline 2009 & \multicolumn{2}{|c|}{ Daily Maximum } & \multicolumn{3}{|c|}{ Daily Minimum } \\
\hline & $\begin{array}{c}\mathrm{L} \\
(\mathrm{kWh})\end{array}$ & $\begin{array}{c}\mathrm{G} \\
(\mathrm{kWh})\end{array}$ & $\begin{array}{l}\mathrm{G} / \mathrm{L} \\
(\%)\end{array}$ & $\begin{array}{c}\mathrm{L} \\
(\mathrm{kWh})\end{array}$ & $\begin{array}{c}\mathrm{G} \\
(\mathrm{kWh})\end{array}$ & $\begin{array}{c}\mathrm{G} / \mathrm{L} \\
(\%)\end{array}$ \\
\hline Jan & 102592 & 11687 & 17.45 & 66973 & 744 & 0.73 \\
\hline Feb & 96698 & 15245 & 18.58 & 68231 & 1070 & 1.34 \\
\hline Mar & 97809 & 18218 & 28.71 & 61621 & 2758 & 2.84 \\
\hline Apr & 90506 & 18155 & 23.43 & 59041 & 2330 & 3.50 \\
\hline May & 92729 & 21483 & 33.07 & 62029 & 5622 & 6.62 \\
\hline Jun & 99953 & 21352 & 34.96 & 60263 & 4649 & 5.23 \\
\hline Jul & 100803 & 21041 & 30.16 & 69759 & 10766 & 13.36 \\
\hline Aug & 99491 & 18702 & 26.19 & 64797 & 7104 & 9.56 \\
\hline Sep & 99969 & 16441 & 24.82 & 65314 & 2812 & 3.48 \\
\hline Oct & 105461 & 15849 & 25.00 & 61130 & 861 & 0.96 \\
\hline Nov & 96180 & 13315 & 17.08 & 65802 & 1156 & 1.68 \\
\hline Dec & 99295 & 11674 & 15.60 & 66599 & 678 & 0.86 \\
\hline
\end{tabular}

Table V. - Results of the daily analysis for 2010.

\begin{tabular}{|l|r|c|c|r|r|r|}
\hline 2010 & \multicolumn{2}{|c|}{ Daily Maximum } & \multicolumn{3}{|c|}{ Daily Minimum } \\
\hline & $\begin{array}{c}\mathrm{L} \\
(\mathrm{kWh})\end{array}$ & $\begin{array}{c}\mathrm{G} \\
(\mathrm{kWh})\end{array}$ & $\begin{array}{c}\mathrm{G} / \mathrm{L} \\
(\%)\end{array}$ & $\begin{array}{c}\mathrm{L} \\
(\mathrm{kWh})\end{array}$ & $\begin{array}{c}\mathrm{G} \\
(\mathrm{kWh})\end{array}$ & $\begin{array}{c}\mathrm{G} / \mathrm{L} \\
(\%)\end{array}$ \\
\hline Jan & 97580 & 11064 & 14.58 & 50300 & 655 & 0.83 \\
\hline Feb & 97914 & 14408 & 19.08 & 64412 & 998 & 1.07 \\
\hline Mar & 95517 & 17177 & 22.00 & 65417 & 2089 & 2.34 \\
\hline Apr & 97469 & 18669 & 29.57 & 62193 & 2875 & 3.26 \\
\hline May & 96302 & 20801 & 27.61 & 58764 & 3334 & 4.05 \\
\hline Jun & 90746 & 21424 & 27.20 & 58586 & 3892 & 5.19 \\
\hline Jul & 99761 & 21138 & 26.60 & 66490 & 6528 & 7.84 \\
\hline Aug & 103777 & 20069 & 25.45 & 65958 & 4601 & 5.71 \\
\hline Sep & 101421 & 17703 & 24.72 & 69185 & 2355 & 2.56 \\
\hline Oct & 109341 & 15240 & 16.87 & 66767 & 1533 & 1.70 \\
\hline Nov & 99181 & 13675 & 16.84 & 68510 & 379 & 0.55 \\
\hline Dec & 101523 & 12096 & 16.47 & 71933 & 970 & 1.00 \\
\hline
\end{tabular}

A set of relevant results can be deduced from the data shown in the tables; these results are referred to the maximum and minimum daily average values. The daily load peak values were between 90 and 110 MWh, achieving the maximum value, for both years, in October (with 105461 and $109341 \mathrm{kWh}$ ). The months with the minimum daily peak load values were April, in 2009, and June, in 2010, with values of 90506 and $90746 \mathrm{kWh}$, respectively.

On the other hand, the minimum daily load values ranged from 50 to 72 MWh, corresponding to January 2010 the day with the minimum daily load (50300 kWh). December 2010 exhibited a peculiar behaviour with all the days with a daily load over $71933 \mathrm{kWh}$. 
With respect to the PV generation, the daily maximum values ranged from 11 to $21.5 \mathrm{MWh}$. The maximum daily generation values correspond to days in May 2009 and June 2010 (24483 and $24424 \mathrm{kWh}$, respectively). The worst PV generation values ranged from $379 \mathrm{kWh}$ (December 2010) to 10766 kWh (July 2009). During all the day in July 2009, the PV daily generation value was, at least, $10766 \mathrm{kWh}$.

The maximum penetration level was $34.95 \%$ (June 21, 2009). The most favourable month was July 2009, with a minimum daily penetration level value of $13.36 \%$, and a maximum of $30.16 \%$ (in July 2010 the minimum and maximum were $7.84 \%$ and $26.6 \%$, respectively).

In Figure 4 are plotted the daily average penetration level for all the days of July in both years. July corresponds to the month with greater PV generation values with respect to the load values.

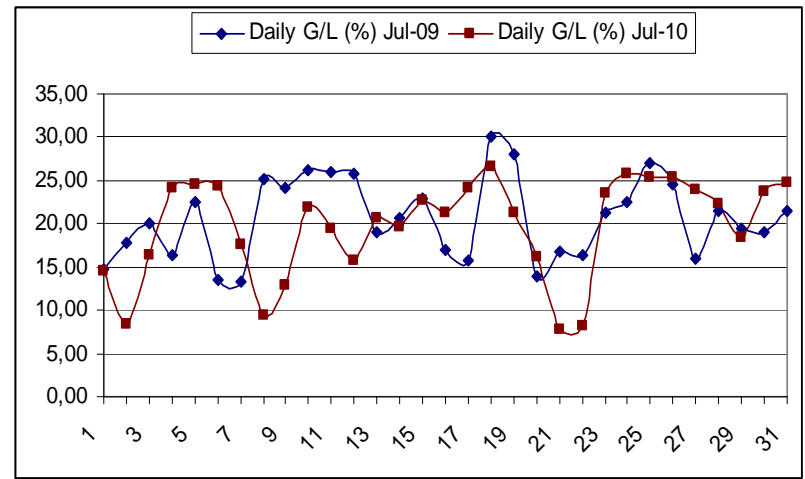

Fig. 4. Daily average penetration level.

Notice that in the month of July, the PV plant fed an important percentage of the load (average values near $20 \%)$.

Figure 5 shows the mean daily average load values. As it's shown, the load values were very similar for both years, except for the months of June and March. The mean daily average values range from 77 to $90 \mathrm{MWh}$. Notice that the maximum load values correspond to the autumn and winter seasons, and the minimum values correspond to spring months.

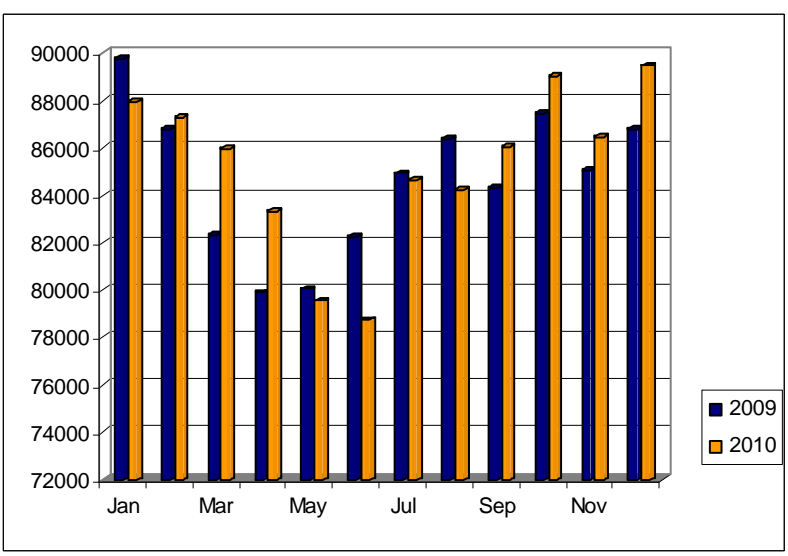

Fig. 5. Mean daily average load values.
Figure 6 shows the mean daily average PV generation values. The values for both years are very similar, showing in the figure a bell shape, with the maximum values in the middle of the year, and, obviously, the minimum values around the end and the beginning of the year.

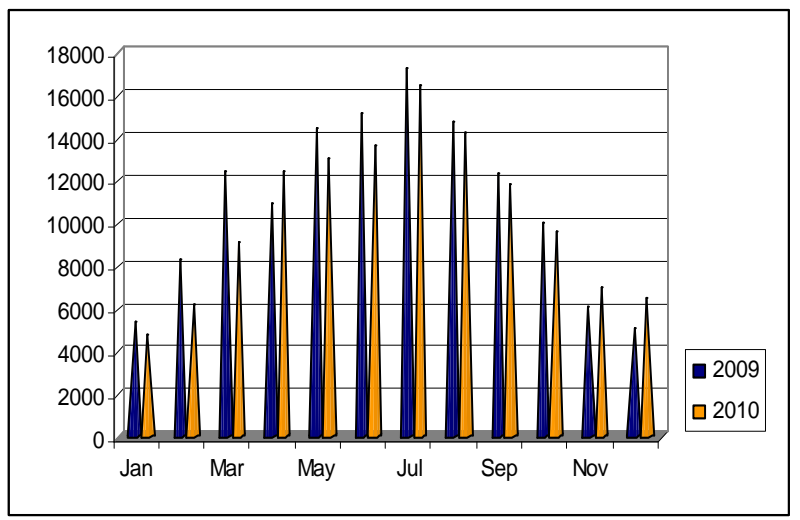

Fig. 6. Mean daily average PV generation values.

If we compare the data plot in figures 5 and 6 , the maximum PV generation values coincide with the minimum load values, as a consequence of the greater number of daylight hours in the middle of the year.

Figure 7 shows the mean daily average penetration levels. The shape of the curve for both years is similar to the corresponding to the mean daily average PV generation. The penetration level is greater than $5 \%$ for winter months, and greater than $10 \%$ for spring and summer months. The maximum mean average penetration level corresponds to the month of July, with level over $20 \%$ in both years.

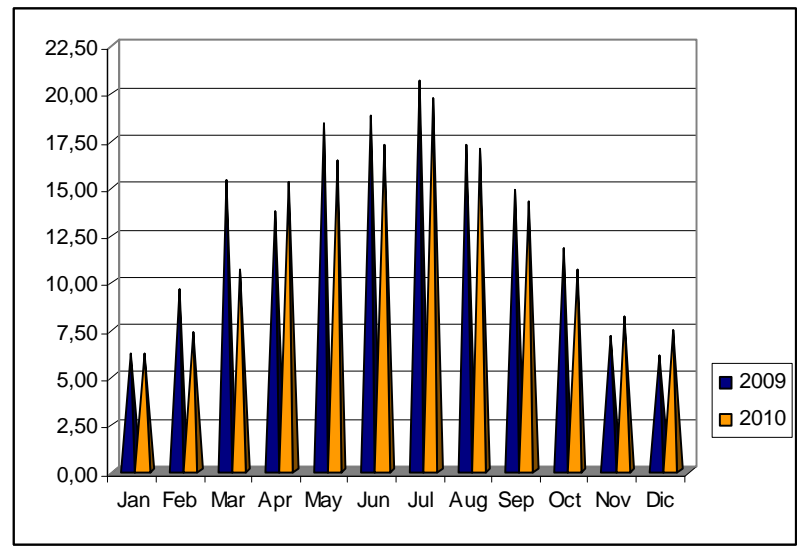

Fig. 7. Mean daily average penetration level.

Tables VI to IX show the data corresponding to days with maximum or minimum temperature values. Table VI includes the data referred to the days (one in each year) with the maximum average temperature, and also includes the average load, PV generation and penetration level values. Table VII includes the data referred to the days with the maximum peak temperatures, and also includes the load, PV generation and penetration level values for the hours corresponding to the maximum temperature. Tables VIII and IX are similar to Tables VI and VII, but including the minimum temperature, instead 
of the maximum temperature. The hourly average load and PV generation values for the day presented in tables VI to IX are plotted in Figure 8 (maximum temperatures), and in Figure 9 (minimum temperatures).

Table VI. - Maximum average temperature days.

\begin{tabular}{|c|c|c|c|c|c|}
\hline Date & $\begin{array}{c}\text { Range T } \\
\left({ }^{\circ} \mathrm{C}\right)\end{array}$ & $\begin{array}{l}\text { Average } \\
\mathrm{T}\left({ }^{\circ} \mathrm{C}\right)\end{array}$ & $\begin{array}{c}\mathrm{L} \\
(\mathrm{kWh})\end{array}$ & $\begin{array}{c}\mathrm{G} \\
(\mathrm{kWh})\end{array}$ & $\begin{array}{l}\mathrm{G} / \mathrm{L} \\
(\%)\end{array}$ \\
\hline $22-07-200$ & $\begin{array}{ll}17 & 39.4\end{array}$ & 28.7 & 96714 & 15931 & 16.47 \\
\hline $26-08-2010$ & $22.6 \quad 41$ & 30.4 & 103777 & 12579 & 12.12 \\
\hline
\end{tabular}

Table VII. - Maximum peak temperature days.

\begin{tabular}{|c|c|c|c|c|c|}
\hline Date & Hour & $\begin{array}{c}\text { Max. T } \\
\left({ }^{\circ} \mathrm{C}\right)\end{array}$ & $\begin{array}{c}\mathrm{L} \\
(\mathrm{kWh})\end{array}$ & $\begin{array}{c}\mathrm{G} \\
(\mathrm{kWh})\end{array}$ & $\begin{array}{c}\mathrm{G} / \mathrm{L} \\
(\%)\end{array}$ \\
\hline $22-07-2009$ & $16-17$ & 39.4 & 4562 & 1347 & 30.07 \\
\hline $26-08-2010$ & $16-17$ & 41 & 5196 & 1104 & 21.25 \\
\hline
\end{tabular}

Table VIII. - Minimum average temperature days.

\begin{tabular}{|c|c|c|c|c|c|}
\hline Date & $\begin{array}{c}\text { Range T } \\
\left({ }^{\circ} \mathrm{C}\right)\end{array}$ & $\begin{array}{l}\text { Average } \\
\mathrm{T}\left({ }^{\circ} \mathrm{C}\right)\end{array}$ & $\begin{array}{c}\mathrm{L} \\
(\mathrm{kWh})\end{array}$ & $\begin{array}{c}\mathrm{G} \\
(\mathrm{kWh})\end{array}$ & $\begin{array}{l}\text { G/L } \\
(\%)\end{array}$ \\
\hline $18-12-2009$ & -6.54 .9 & -0.4 & 96267 & 3786 & 3.93 \\
\hline 29-11-2010 & $\begin{array}{ll}-6.53 \\
\end{array}$ & -0.2 & 96502 & 2250 & 2.50 \\
\hline
\end{tabular}

Table IX. - Minimum peak temperature days.

\begin{tabular}{|c|c|c|c|c|c|}
\hline Date & Hour & $\begin{array}{c}\text { Min. T } \\
\left({ }^{\circ} \mathrm{C}\right)\end{array}$ & $\begin{array}{c}\mathrm{L} \\
(\mathrm{kWh})\end{array}$ & $\begin{array}{c}\mathrm{G} \\
(\mathrm{kWh})\end{array}$ & $\begin{array}{c}\mathrm{G} / \mathrm{L} \\
(\%)\end{array}$ \\
\hline $18-12-2009$ & $2-3$ & -6.4 & 2600 & 0 & 0 \\
\hline $29-11-2010$ & $8-9$ & -6.5 & 3934 & 0 & 0 \\
\hline
\end{tabular}

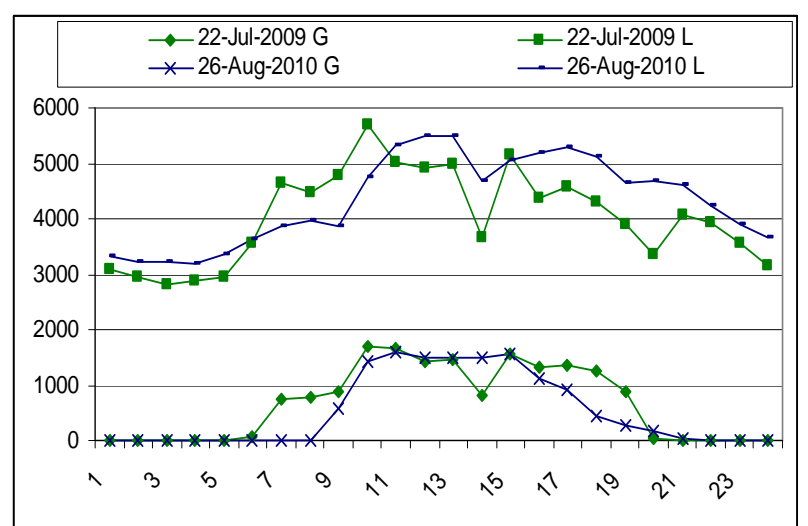

Fig. 8. Hourly average load and PV generation for the days with maximum temperature.

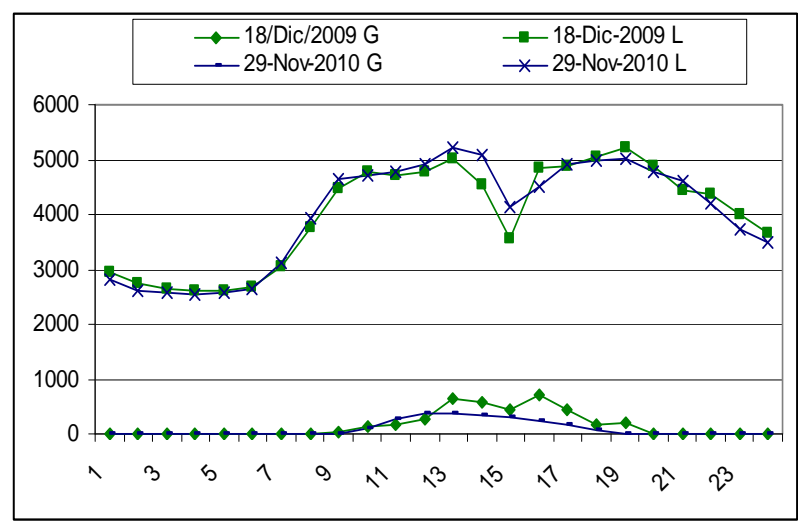

Fig. 9. Hourly average load and PV generation for the days with minimum temperature
Lastly, in Figure 10 are plotted the hourly average load and PV generation values corresponding to the day with the largest average generation in the PV plant (May 31, 2009). For that day the total generation was $21483 \mathrm{kWh}$, about $33.07 \%$ of the load. The temperature values for that day ranged from 8.5 to $22.5{ }^{\circ} \mathrm{C}$, with an average value of $14.6{ }^{\circ} \mathrm{C}$.

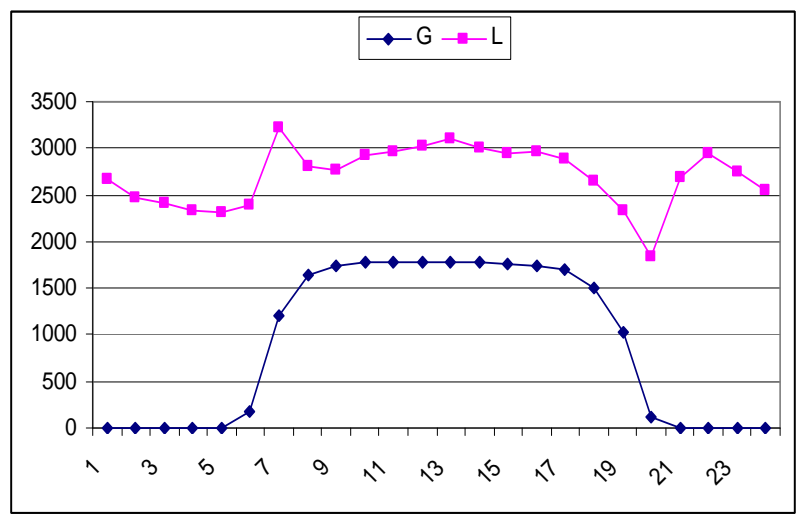

Fig. 10. Hourly average load (L) and PV generation (G) for May 31, 2009.

In the last figure we can observe that the PV plant maintains a regular behaviour for the daylight hours, generating electric energy in a regular manner in the range 1700 to $1800 \mathrm{kWh}$.

\section{Conclusions}

In view of the results obtained, we can gather the following:

- The electric load for this small power system (distribution network under study) has a similar behaviour for the two years of the studied period [5]. The PV generation produces energy at peak hours of the electric load and can cover $43 \%$ of global load in the best moment, with an average contribution of $20 \%$ for all the period.

- Taking into account the similar behaviour of PV generation in both years, and using forecasts of weather variables (temperature, wind speed, solar radiation, etc.), it would be possible to develop a short-term forecasting model for the PV generation.

- Due to the difficulty for storing electric energy to the proper scale, and having as objective to use all the energy generated in PV plant, we propose the application of demand side management actions, as well as the construction of new plants based on other renewable sources that allow to the system to be selfsufficient $[1,2,3,4]$.

\section{Acknowledgement}

The authors would like to thank the "Ministerio de Ciencia e Innovación" of the Spanish Government for supporting this research under the Project ENE2009- 
14582-C02-02, and thank to Electra Autol S.A. for providing the data needed in this study.

\section{References}

[1] Ali Al-Alawi, S.M Islam. "Demand side management for remote area power supply systems incorporating solar irradiance model”. Renewable Energy 29 (2004), pp.2027-2036.

[2] Fatih O. Hocaoglu, Omer N. Gerek , Mehmet Kurban. "A novel hybrid (wind-photovoltaic) system sizing procedure". Solar Energy 83 (2009), pp.2019-2028.

[3] Pedro S. Moura, Anibal T. de Almeida. "Multi-objective optimization of a mixed renewable system with demand-side management”. Renewable and Sustainable Energy Reviews 14 (2010), pp. 1461-1468.

[4] I.G. Mason, S.C.Page, A.G.Williamson. “A 100\% renewable electricity generation system for New Zealand utilising hydro, wind, geothermal and biomass resources”. Energy Policy 38 (2010), pp. 3973-3984.
[5] I.J. Ramírez-Rosado, E. Zorzano-Alba, M. Mendoza Villena, P. Lara-Santillán, E. García-Garrido, L. A. FernándezJiménez, P. Zorzano-Santamaría, E. Tarancón-Andrés. "Load Management Effects in Electricity Distribution Networks". International Conference on Modelling, Identification and Control, Innsbruck, Austria (2003), pp 246-249.

[6] A. Gabaldon, A. Molina, C. Roldán, J.A. Fuentes, E. Gomez, I.J. Ramírez-Rosado, P. Lara, J.A. Domínguez, E. García, E. Tarancón. "Assessment and Simulation of DemandSide Management Potential in Urban Power Distribution Networks”. IEEE Power Technology Conference (PowerTech), Bologna, Italy (2003).

[7] I.J. Ramírez-Rosado, E. Tarancón-Andrés, "Improvement Of Residential Distribution Systems Operation Via Efficient Electrical. End-Uses Appliances”, Proceedings of the $23 \mathrm{rd}$ IASTED International Conference on Modelling, Identification and Control, Switzerland (2004), pp. 402-405.

[8] I.J. Ramírez-Rosado, E. Tarancón-Andrés, "DSM actions and optimal design of residential power distribution systems", Proceedings of the 23 rd IASTED International Conference on Modelling, Identification and Control, Switzerland (2004), pp. 406-410. 